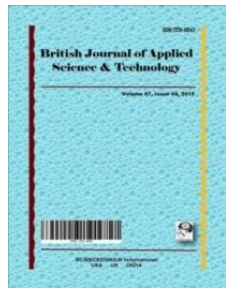

British Journal of Applied Science \& Technology

10(4): 1-6, 2015, Article no.BJAST.17970

ISSN: 2231-0843

SCIENCEDOMAIN international

www.sciencedomain.org

\title{
Obtained Yield and Financial Parameters of Organically Grown Mint in the Republic of Macedonia
}

\author{
Ljupcho Mihajlov ${ }^{1 *}$, Vasko Zlatkovski ${ }^{2}$ and Natalija Markova Ruzdik ${ }^{1}$ \\ ${ }^{1}$ Department of Plant Production, Goce Delchev University, Faculty of Agriculture, \\ ul.KrsteMisirkov br.10A, p.f.201, Shtip 2000, Republic of Macedonia. \\ ${ }^{2}$ Department of Plant and Environment Production, Goce Delchev University, Faculty of Agriculture, \\ ul.KrsteMisirkov br.10A, p.f.201, Shtip 2000, Republic of Macedonia.
}

\begin{abstract}
Authors' contributions
This work was carried out in collaboration between all authors. All authors read and approved the final

manuscript.

Article Information

DOI: 10.9734/BJAST/2015/17970

Editor(s):

(1) Ahmed Mohamed El-Waziry, King Saud University, College of Food and Agriculture Sciences, Kingdom of Saudi Arabia. (2) Hamid El Bilali, Mediterranean Agronomic Institute of Bari (CIHEAM/IAMB), Sustainable Agriculture, Food \& Rural Development Department, Via Ceglie 9, 70010 Valenzano (Bari), Italy.

(1) Walid Fediala Abd El-Gleel Mosa, Plant Production Department, Alexandria University, Egypt. (2) Anonymous, Agricultural Research Council, South Africa. (3) Anonymous, Thammasat University, Thailand.
(4) Raul Leonel Grijalva Contreras, Instituto Nacional de Investigaciones Forestales Agrícolas y Pecuarias, Mexico. (5) Anonymous, Universidade Regional Integrada do Alto Uruguai e das Missões, Brazil. Complete Peer review History: http://sciencedomain.org/review-history/10040
\end{abstract}

Original Research Article

Received $31^{\text {st }}$ March 2015

Accepted $10^{\text {th }}$ June 2015

Published 6 ${ }^{\text {th }}$ July 2015

\section{ABSTRACT}

Aims: The objective of this paper is to present the soil and weather conditions, applied production technology and to demonstrate the economic viability of irrigated and organically grown Mint (Mentha piperita).

Methodology: The obtained yield results are in reference to the open field growing conditions. In order to present the results in clear and understandable manner, standard methods for cost calculation were applied, usual for organic plant production. In order to obtain comparable results, the processed data in this paper are from the two-year production trials (2009 and 2010), of a newestablished mint plantation planted in October 2008, in the region of Ovche Pole - central part of the Republic of Macedonia.

Results: In the first year of utilization (2009), two cuttings were performed yielding $3500 \mathrm{~kg} / \mathrm{ha}$ of 
above-ground dry mass. In the second year of utilization (2010), there were three cuttings yielding $5155 \mathrm{~kg} / \mathrm{ha}$ of above-ground plant dry mass. Economic analysis proves that profitability in organically produced Mint (Mentha piperita) is obtained in the second growing season year, recording profit of $€ 8125$ per hectare.

Conclusion: Based from the obtained results the benefits of growing Mint are: opportunities to optimize yield and achieve uniform high quality product. Organic way of growing Mint, can be a great business idea for the farm and family business.

Keywords: Mint; organic farming; yield; profitability.

\section{INTRODUCTION}

The origin of peppermint species cannot be determined. Dried leaves were found in ancient times, in the Egyptian pyramids. Two species of mint were used by the ancient Greek physicians. However, some writers debate whether one is the modern peppermint, though there is evidence that $M . x$ piperita was cultivated by the Egyptians [1]. It is thought to be a natural hybrid between spearmint (M. spicata Linn. emend. Nathh.) and water mint ( $M$. aquatic Linn), the latter itself being a hybrid of $M$. longifolia (Linn.) Huds, and $M$. rotundifolia (Linn.) Huds so $M$. piperita is a triple hybrid [2]. Mint is popular medicinal plant in several traditional systems of medicine. Medicinal, aromatic and the spice plants are widely used in pharmaceutical, food, cosmetics, alcoholic beverage industries and as well as in chemical (pesticide) industry. Up to the mid '50's of the last century, these plants were used as raw material from wild flora of these species, and some plants still are used how growing wild plants [3]. The WHO has estimated that more than $80 \%$ of the world's population in developing countries when satisfying basic health care needs depend primarily on herbal medicine. Approximately two thirds of the 50000 different medicinal plant species which are in use are collected out in the wilderness [4]. As far as production levels are concerned, the volume is estimated on more than 4000 t/year. Almost $80 \%$ of it is produced in USA. Mint production is also organized in Canada, UK, Australia and New Zealand, while in Asia this crop is mostly grown in India and China [5]. In South Africa under irrigation and good management, peppermint will yield 20 to 25 tons of plant material per hectare per year, at an oil recovery rate of $0,3 \%$ or 60 to $75 \mathrm{~kg}$ essential oil per ha. [5]. In Europe only $10 \%$ of medicinal species which are in commercial use are cultivated. Cultivation of some herbs has proved difficult because of low germination rate or specific ecological requirements [3]. Mints are widely cultivated on almost all types of soils and climates. The major commercially produced species are: Japanese or menthol mint (Mentha arvensis $L$. var. piperascens), peppermint (M. piperita L.), common or native spearmint (M. spicata $L$.), Scotch spearmint (M. cardiaca Baker), garden mint $(M$. viridis $L$.) and bergamot mint $(M$. citrata Ehrh). China, India, U.S.A, Japan, France, Italy, Russia and Bulgaria are some of the major producers of mint oils [6]. Peppermint Mentha piperita L., which is used in production of flavors, fragrances and pharmaceuticals, were investigated for their antimicrobial properties against 21 human and plant pathogenic microorganisms.

Three of the largest producers of mint and mint related products, (such as essential oils) are the United States, India and China [7]. The U.S.A and India produce the largest supplies of mint oil used in chewing gum, toothpaste, mouthwash and several other products. Irrigation and nitrogen should be in adequate quantities for maximum growth; plant stress causes early bloom and production of menthofuran which reduces oil quality for some markets [8]. Republic of Macedonia has very favorable geographic position, diversity of soil types and low contamination of natural resources which provides conditions for cultivation of aromatic, spice and medical plants. The advantages of the Macedonian territory for organic cultivation of the medicinal aromatic and spice plants are: Areas with low degree of pollution or unpolluted resources (soil, water, air); Favorable geographical position, diverse landscape; fertile river valleys, flat lowlands and mountain slopes; diverse types of the soils. Naturally, there are weaknesses and these are: Unused agroenvironment potentials; Lack of Macedonian literature for growing technology of aromatic \& medicinal herbs and spices; Lack of exploration experience in this area; Lack of skills on farmer level on growing methodology for certain aromatic spices and medicinal plants; Lack of 
devised strategy for cultivation medicinal plants that can penetrate on the market; Lack of information on potential yields, prices and markets for this group of the plants. Unfortunately, this is the first research attempts for growing Mint under the soil \& weather conditions in the central part of Macedonia, hence we're unable to compare our results with any previously obtained, as they do not exist. Generally, the purpose of publishing this paper is to inform on the possibilities and the benefit of growing Mint under the organic principles in Macedonia.

\section{MATERIALS AND METHODS}

Major components of Mentha piperita essential oils identified by Gas Chromatography (GC) and Gas Chromatography-Mass Spectrometry (GC/MS) are: limonene 1-2.1\%, 1,8-cineole 3.4$5.3 \%$, menthone $18.4-27.9 \%$, menthofuran 1.3$5.5 \%$, isomenthon $2.9-3.8 \%$, linalool $2.5-4.8 \%, \beta-$ caryophyllene, $1.5-4.2 \%$, terpinen-4-ol 1.2-3.8\%, menthol $27.5-42.3 \%$, pulegone $1.0-14.4 \%$, aterpineol/borneol $0.7-2.4 \%$ [9].

Difference in the values of the percentages of individual components in peppermint oil due to the different places of production of mint i.e. the different agro-ecological conditions [2]. Ovche Pole valley (GPS coordinates: N 41049', E $21^{\circ}$ $\left.59^{\circ}\right)$, suffers negative effect by being overlapping area of two climate types. The Mediterranean and Continental climate, which are the main reason for inconsistent and uneven precipitation, especially in the summer when there are significant low precipitation values [4]. The soil on which Mint was cultivated according to the principles of organic farming belongs to vertisol type. Its characteristic and nutrient availability are presented in Table 1 (total area of 2 ha).

Table 1. Agrochemical analysis of soil from experimental field in Ovche Pole

\begin{tabular}{lc}
\hline Analyzed parameters & Location \\
\cline { 2 - 2 } & Ovche Pole \\
\hline Available $\mathrm{P}_{2} \mathrm{O}_{5}(\mathrm{mg} / 100 \mathrm{~g}$ soil) & 24.19 \\
Available $\mathrm{K}_{2} \mathrm{O}(\mathrm{mg} / 100 \mathrm{~g}$ soil) & 74.1 \\
Humus $(\%)$ & 1.94 \\
Conductivity (mS/cm) & 0.25 \\
Total N (mg/g) & 0.98 \\
pH & 7.65 \\
\hline
\end{tabular}

The results from the agrochemical soil analysis presented in Table 1, performed on the soil from the trial fields on which the Mint was planted in
Ovche Pole, indicates that the soil is with the following characteristics: good phosphorus availability $(24.19 \mathrm{mg} / 100 \mathrm{~g})$, rich in availability of potassium $(74.1 \mathrm{mg} / 100 \mathrm{~g})$, poor in humus content $(1.94 \%)$ and slightly increased salinity [10]. The total nitrogen level is on satisfactory level $(0.98 \mathrm{mg} / \mathrm{g})$ while the $\mathrm{pH}$ value is on the alkaline side (7.65). Applied production technology of organically grown Mint, can be seen from data stated below, as well as from Table 4, named as: Revenues and incomes in the year of establishment (2008) and in the first year of utilization (2009). Planting was mechanized, with certificated quality propagation material with a length of $10-15 \mathrm{~cm}$. Spacing between the rows was $70 \mathrm{~cm}$. Width of rows was planned in a way to avoid plant damage during mechanized inter row cultivation for wee control. In our case, the Peppermint was planted by the end of October 2008. The new plants were watered immediately after transplanting. During the vegetation, in the stage of most intensive growth (up to the first cut) the prevention of the weeds was performed by 2 treatments between rows with cultivator. In-row weeds were reduced manually. Between each mowing, irrigation was applied using sprinklers providing $50 \mathrm{l} / \mathrm{m}^{2}$ of water. Peppermint has a shallow root system and requires frequent irrigation with short sets, thus additional labor is required for moving irrigation equipment in peppermint compared to most field crops [7]. In the first year of exploitation (2009), due to youth fullness of the growing crop only two mowing were performed. The next year (2010), the number of mows increased by one. Practices described are based on production practices considered typical for the crop and area, but will not apply to every situation.

\section{RESULTS AND DISCUSSION}

\subsection{Biomass Productivity}

Timing and types of establishment and cultural practices will vary among growers within the region and from season to season due to variables such as weather, soil, and insect and disease pressure [8]. Besides favorable agro climatic conditions for the production of high quality dried herb material, plants responds quite well to good irrigation and fertilizer management. As [11] indicates, the area of Ovche Pole is characterized by moderate low average amount of rainfall $\left(640-750 \mathrm{l} / \mathrm{m}^{2}\right)$. Fig. 1 illustrates that ten years rainfall average (2001-2011), as well as average monthly precipitation in the years of study (2009-2010), can be seen that in July, 
August and September, the average monthly precipitation values are lowest. From the abovementioned, it can be noted that for the cultivation of mint in this region, and to get more than two mowing, it is necessary to irrigate, especially in the months with low precipitation.

Production of dried mint herb in these analyses ranged from $3500 \mathrm{~kg} / \mathrm{ha}$ in first year of exploitations (2009), up to $5155 \mathrm{~kg} / \mathrm{ha}$ in the following year (2010), as presented in Table 2 below, where it is presented and the ratio between dry leaves and stems.

The analysis of organic mint production (baled dry mass), subject of this paper are grouped in accordance and mutual dependence of applied specific agricultural techniques and administrative expenses

\subsection{Financial Results}

In order to check the financial effect of the suggested crop, for which any crop would be interesting to the producers (in this case-the Mint), it was necessary to determine the production costs [12]. The determination of the economic effect of the production of organic Mint, gives opportunity to the producers for greater visibility, monitoring and planning of all activities in accordance with cost operations. Calculation of costs and the incomes in the production of organic mint in the year of establishment (2008) and in first year of utilizing (2009), includes many elements. These can be grouped depending on the price of certain agro-technical measures and certain administrative costs (Table 3 ).

Table 4 presents that the overall cost structure, costs for propagating material, (underground stolons) are with biggest share $(51.7 \%)$. Due to the large volume of investments in the first year of establishment, the cost per unit is high (1.9 $€ / \mathrm{kg}$ ). For all the reasons mentioned previously, in the first year of utilizing the profit is significantly lower (1569 €/ha) compared to the second year (2010). Lower yield/profit in the first year of utilization is due to incompletely developed crop growing, and the lower number of mowing.

\subsection{Calculation of the Expenses in the Second Year of Utilizing the Crop (2010)}

In the second year of crop's utilization, the total costs $(€ / \mathrm{ha})$, and the costs per unit $(0,15 € / \mathrm{kg})$, are significantly smaller. The total income is $€$ 19050 (Table 4). The income per unit area is $8125 € /$ ha. Calculation of costs and incomes in the second year of production of organic Mint is presented in Table 4. Data in this Table do not refer to costs for: soil cultivation, organic manure, its application, costs of propagating material and transplanting costs. In the second year of the utilizing the crop, the costs for harvesting and collecting, account for biggest share $(50 \%)$, in the overall cost structure.

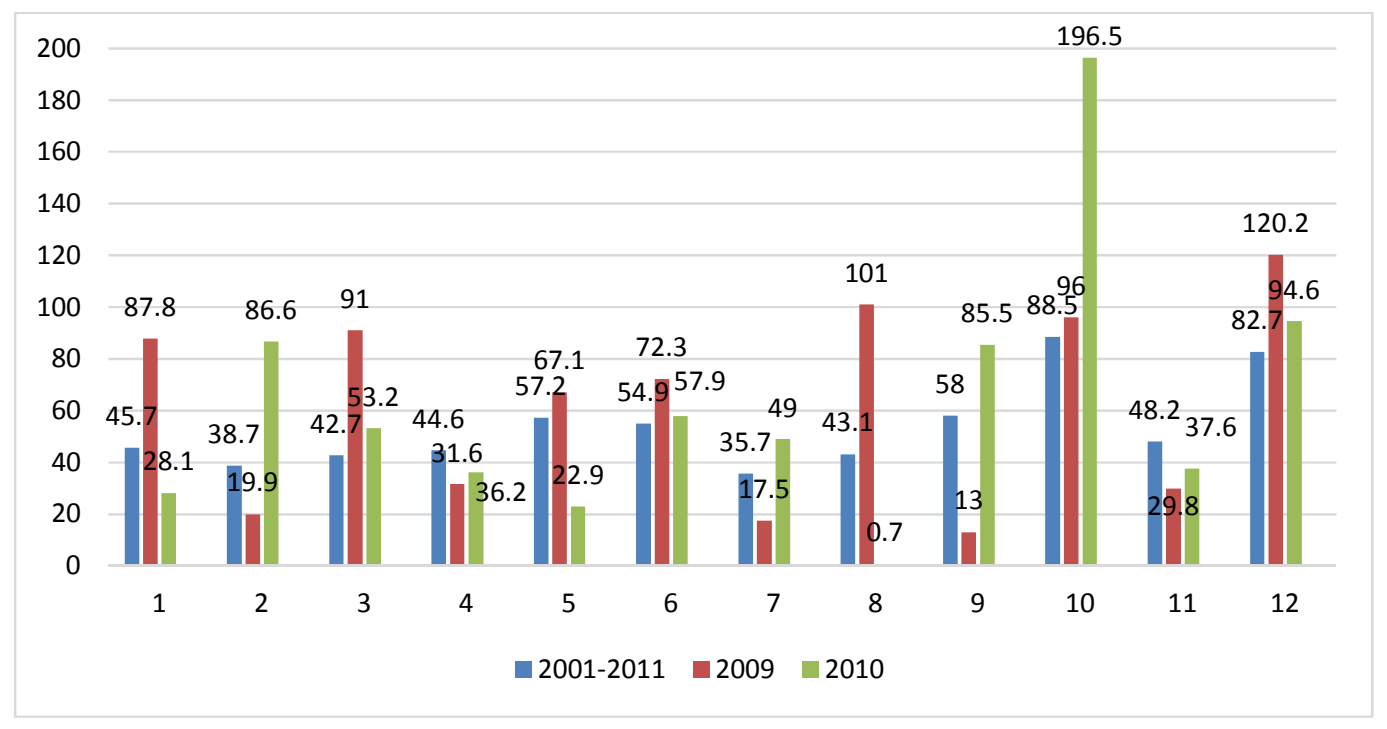

Fig. 1. Monthly amount of precipitation ( $\mathrm{mm}$ ) 
Table 2. Yield of dried mint herb (kg/ha)

\begin{tabular}{lllll}
\hline Year & Leaves & Stems & Leaves + Stems & Ratio \\
\cline { 5 - 5 } & & & Leaves : Stems \\
\hline 2009 & 1900 & 1600 & 3500 & $1,2: 1$ \\
2010 & 3682 & 1473 & 5155 & $1,4: 1$ \\
\hline
\end{tabular}

Table 3. Revenues and incomes in the year of establishment (2008), and in the first year of utilization (2009)

\begin{tabular}{|c|c|c|c|c|c|}
\hline 2008-2009 & Unit & Qty & $\begin{array}{l}\text { Price per } \\
\text { unit }(€)\end{array}$ & $\begin{array}{l}\text { Total } \\
(€)\end{array}$ & $\begin{array}{l}\text { Part of total } \\
\text { income/cost (\%) }\end{array}$ \\
\hline Income obtained from production & $\mathrm{kg}$ & 7000 & 1.77 & 12390 & 93.9 \\
\hline Income from subsidies & ha & 2 & 400 & 800 & 6.1 \\
\hline Total revenues & & & & 13190 & 100.0 \\
\hline Soil cultivation costs & ha & 2 & 310 & 620 & 6.1 \\
\hline $\begin{array}{l}\text { Costs for Organic manure and } \\
\text { application }\end{array}$ & $\mathrm{t}$ & 60 & 30 & 1800 & 17.9 \\
\hline Costs for propagating material & & 4 & 1300 & 5200 & 51.7 \\
\hline Transplanting costs & ha & 2 & 150 & 300 & 3.0 \\
\hline Irrigation costs & ha & 2 & 250 & 500 & 5.0 \\
\hline $\begin{array}{l}\text { Harvesting and collection costs } \\
\text { (two mowing: } 2 \times 233 € \text { ) }\end{array}$ & ha & 2 & 466 & 932 & 9.3 \\
\hline Crop insurance costs & ha & 2 & 250 & 500 & 5.0 \\
\hline Certification costs & ha & 2 & 100 & 200 & 2.0 \\
\hline First year total costs & & & & 10052 & 100.0 \\
\hline Cost of production unit $(€ / \mathrm{kg})$ & & 1.9 & & & \\
\hline Profit per unit area $(€ /$ ha) & & 1569 & & & \\
\hline
\end{tabular}

Table 4. Costs and incomes in the second year of utilizing the crop (2010)

\begin{tabular}{|c|c|c|c|c|c|}
\hline & Unit & Qty & $\begin{array}{l}\text { Price per } \\
\text { unit }(€)\end{array}$ & Total $(€)$ & $\begin{array}{l}\text { Part of total } \\
\text { income/cost (\%) }\end{array}$ \\
\hline Income obtained from production & $\mathrm{kg}$ & 10310 & 1.77 & 18250 & 95.8 \\
\hline Income from subsidies & ha & 2 & 400 & 800 & 4.2 \\
\hline Total income & & & & 19050 & 100.0 \\
\hline Irrigation cost & ha & 2 & 250 & 500 & 17.9 \\
\hline $\begin{array}{l}\text { Harvesting and collection cost } \\
\text { (three mowing: } 3 \times 233 € \text { ) }\end{array}$ & ha & 2 & 700 & 1400 & 50.0 \\
\hline Crop insurance cost & ha & 2 & 250 & 500 & 17.9 \\
\hline Certification cost & ha & 4 & 100 & 400 & 14.2 \\
\hline Total costs & & & & 2800 & 100.0 \\
\hline Cost of production unit $(€ / \mathrm{kg})$ & & & & 0.15 & \\
\hline Profit per unit area $(€ / \mathrm{ha})$ & & & & 8125 & \\
\hline
\end{tabular}

If of the total income ( $€$ 19050), total costs are deducted $(€ 2800)$, obtained value refer for second year profit (2010), which amounts to total of $€ 16250$ or profit per unit area of $8125 € /$ ha.

\section{CONCLUSION}

Mint organic production has a lot of advantages because:
- The characteristics of the obtained product is suitable for extended storage in controlled conditions;

- Provides opportunities for monitoring and market analysis and possibly getting a higher price;

- Excludes the application of synthesized chemicals for nutrition and protection of the growing crop; 
- Provides agro ecosystem sustainability through maintenance of biodiversity and antipollution impact on natural ecosystems for future generations.

- It can to optimize yield and achieve uniform high quality product.

- Relatively higher profit margin, through organic way of growing, can be a great business idea for the farm and family business.

- At last, but no least important, following the profitability results of growing organic Mint, appears that this production orientation could be of great business opportunity for Macedonian farmers.

\section{COMPETING INTERESTS}

Authors have declared that no competing interests exist.

\section{REFERENCES}

1. Du Preez R. Herbs for the garden. Nelspruit, South Africa: ARC-Institute for Tropical and Subtropical Crops. 2005;7.

2. Fleming T. PDR for herbal medicines, Montvale, NJ: Medical Economics Company, Inc. 1998;5.

3. Vines G. Herbal harvests with a future: towards sustainable sources for medicinal plants, Plant life International; 2004. Available:http://www.plantlife.org.uk (Accessed 2014)

4. Edwards R. No remedy in sight for herbal ransack. New Sci. 2004;181:10-11.

5. Directorate Communication Services, Department of Agriculture, Forestry and Fisheries. Peppermint production. 2012;2-3.
Available:http://www.nda.agric.za/docs/Bro chures/ProGuiPeppermint.pdf

6. Kalra A, Singh HB, Pandey R, Samad A, Patra NK, Kumar S. Diseases in mint: causal organisms, distribution, and control measures. J. Herbs Spices Med. Plants. 2004;11:71-95.

7. Jonathan D. Septer. Top countries for Mint production.

Available:http://www.ehow.com/list 65482

94 top-countries-mint-plantproduction.html

(Accessed 02 June 2014)

8. Wilson $\mathrm{R}$, Marcum DB, Klonsky KM, De Moura. Sample costs to establish a mint stand and produce pepermint oil Intermountain Region. University of California Cooperative Extension. Peppermint Costs and Returns Study Intermountain Region UC Cooperative Extension. 2011;3.

9. Iscan G, Kirimer N, Kurkcuoglu M, Husnu Can Baser K, Demirci F. Antimicrobial screening of Mentha piperita essential oils. J. Agric. Food Chem. 2002;50:3943-3946.

10. Mihajlov Lj, llieva V, Markova N, Zlatkovski V. Organic cultivation of lemon balm (Melissa officinalis) in Macedonia. Journal of Agricultural Science and Technology B. 2013;3(11):769.

11. Filipovski $\mathrm{G}$, et al. Characteristics of the climate-vegetation-soil zones (regions) in the Republic of Macedonia. MASA, Skopje. 1996;25-30.

12. Mihajlov LJ, Kletnikoski P. Economic effects from production of organic alfalfa under irrigation in Ovce Pole. Goce Delcev University - Stip, Faculty of Agriculture, Yearbook. 2008;8:97.

(c) 2015 Mihajlov et al.; This is an Open Access article distributed under the terms of the Creative Commons Attribution License (http://creativecommons.org/licenses/by/4.0), which permits unrestricted use, distribution, and reproduction in any medium, provided the original work is properly cited.

Peer-review history:

The peer review history for this paper can be accessed here: http://sciencedomain.org/review-history/10040 